\title{
A model of personal-oriented training of bachelors of technical profile for high-tech industries
}

Nataliya Nikolaevna Saveleva ${ }^{a}$

\section{Abstract}

The higher education in Russia is now divided into two stages: Bachelor's and Master's degrees. Regretfully, the educational process of baccalaureate students has revealed unsatisfactory preparation of young specialists, who have to undergo further training and adaptation to a high-tech industry. The lack of professional competencies of graduating students is rather disappointing for employers. Therefore, it becomes vital to improve the educational process and implement significant changes to the methodological system of education. It is necessary to encompass information technologies. This study is devoted to the educational program for mechanical engineers, which has been developed according to the main employers requirements. The effectiveness of this training approach was proved during the research experiment. It proved the hypothesis that the improved model of student training: leads to a more active and effective studying process, incorporates an individual approach to each student, and contributes to a more efficient development of professional competencies.

Keywords: Personality-oriented preparation. Design activities. Production and technological activities. Research activities. High-tech manufacturing.

\section{Introduction}

At present, the main goal of Russian higher education is to provide highly qualified specialists capable of professional growth in conditions of rapid technological changes and the introduction of new innovative equipment. Higher professional education in Russia recently moved to a two-step system of education, namely Bachelor's and Master's degrees. At the same time, the practice that is still insufficient to prepare bachelors shows that the use of traditional educational technologies and traditional didactic aids with significantly reduced time for

a University of Tyumen, Tyumen, Russian Federation.

Received: 18 apr. 2018

Accepted: 10 aug. 2018 
training is not able to provide high-quality training of qualified specialists for modern high-tech industries. For this reason, this research is aimed at finding a solution to an important problem of higher education, that is to say, preparing bachelors for effective professional work in high-tech enterprises.

In recent years, there has been a shortage of technical specialists throughout the world. In Russia, high-tech industry is also experiencing an acute shortage of qualified specialists in technical areas, which is the main reason for the impossibility of rapid modernization and the solution of import substitution tasks. According to the Ministry of Industry and Trade, there is a critical lack of engineering and technical personnel and skilled workers in the following industries: mechanical engineering, the military-industrial complex, and electronics. To meet the needs of all industries in Russia, it is necessary to train bachelors, specialists, and workers with an orientation to the needs of high-tech industries (SAVELEVA, 2018).

\section{Literature review}

By analyzing the scientific literature and by investigating the viewpoints of university lecturers and managers of high-tech industries, the author of this research came to the conclusion that there is a need for a significant change in the methodological system of education, including its content, forms, methods, as well as the methods of education and implementation of the educational process, which is supposed to affect the quality of training of future specialists in comparison with the traditional educational process based on the so-called KAS (knowledge, abilities, and skills) approach.

The study of foreign scientific literature shows that professional education is influenced by such factors as a person's self-development (SOARES, 2006), state education policy (The Washington Accord), quality of education (CHALETA, 2018), etc. Based on the analysis of psychological and pedagogical literature (BATYSHEV, 1998; SLASTENIN, 1999; SOKOLOVA, 2003; SOLOVOV, 2006), and on the author's pedagogical experience, the author comes to the conclusion that it is possible to provide a high-level development of professional competencies in future bachelors in the following way.

1. The implementation of personality-oriented education (SAVELEVA, 2016a; SOKOLOVA; TEREKHINA, 2013; STEPHENSON; TROY, 2003) that implies training of machine-building bachelors based on individual educational trajectories in accordance with their inclinations to future professional activity, in particular, industrial-technological, design-engineering, and research. 
2. The efficiency of preparing bachelors in the technical field is ensured through the use of information technologies (Self-study report for review of the program leading to the degree of Bachelor of Science in Engineering by the ABET, 2001), specially developed program-methodological and didactic teaching aids (GURGEL, 2013).

3. The education of bachelors is conducted in a specially created educational space for engineering activities on modern high-tech equipment in a complex of laboratories at universities.

In Europe and America, there are the following qualifications of technical specialists: engineer, technologist, and technician (CHUCHALIN et al., 2006). Specialists obtain the right to carry outengineering activities if they pass certification and licensing procedures. After the process of specialists' certification, in which applicants' professional competencies are assessed, they receive the status of a Chartered Engineer (England, Australia, Ireland, New Zealand), or Professional Engineer (USA, Japan, South Africa, Canada, etc.).

To create unified requirements for educational programs in the form of a set of competencies, Engineers Mobility Forum (EMF) (ENGINEERS MOBILITY FORUM, 2017) and Engineering Technologists Mobility Forum (ETMF) were established (ENGINEERING TECHNOLOGISTS MOBILITY FORUM, 2017).

In the areas of preparing different levels of education, the following organizations formulate and coordinate a list of professional competencies: Washington Accord for university graduates (INTERNATIONAL ENGINEERING ALLIANCE, 2017a), Sydney Accord for college graduates with the qualification of "a technologist" (INTERNATIONAL ENGINEERING ALLIANCE, 2017b), and Dublin Accord for college graduates with the qualification of "a technician" (INTERNATIONAL ENGINEERING ALLIANCE, 2017c).

In Europe, the certification of engineering personnel is carried out by the European Federation of National Engineering Associations (FEANI), which includes more than 350 engineering and scientific associations, and up to four million professional engineers in 32 European countries (EUROPEAN FEDERATION OF NATIONAL ENGINEERING ASSOCIATIONS, 2017). Besides, FEANI takes an active part in the development and adjustment of the qualification requirements for the professional competencies of graduates of higher and secondary professional institutions. Besides, the current training rules at post-graduate education stage existing in different countries should be studied and systematized in the future (FERREIRA; PACHECO, 2009) 
This experiment is an attempt to bring the training of technical specialists in Russia in accord with the international quality assessment of training specialists for engineering activities and to improve the quality of education.

It is necessary to point out that in order to train a university graduate for successful professional activity in the future, it is necessary to adhere to one of the basic requirements, in other words, carrying out training based on individual educational trajectories. At the same time, a student will have to plan ways of building an individual personal career, which contributes to his future realization as a specialist.

Simultaneously, the choice of a personal path should take into account the inclinations and individual abilities of each student (SAVELEVA, 2016a; SOKOLOVA; TEREKHINA, 2013; STEPHENSON; TROY, 2003). Scientists like G.G. Kravtsova, T.A. Matis, Y.A. Poluyanova, V.V. Rubtsova, G. A. Tsukerman, and I.S. Yakimanskaya conducted theoretical and practical research in the field of personality-oriented teaching. All scientists note the need for an individual approach to teaching. Some authors emphasize that it is necessary to develop a common system of personality-oriented teaching as a basis for students' and schoolchildren's successful education. This system serves the all-round development of each person's personality (O’SULLIVAN, 2003; SOKOLOVA; TEREKHINA, 2013).

Within the framework of an individual approach, school carries out only a differentiation of subjects, which is required later in higher educational institutions, while spiritual and personal orientation is not considered. In higher education, learning models are subordinated to the development of typical intellectual abilities. Intellectual abilities are developed through standard activities in terms of content and structure. The formation and development of personal inclinations and characteristics are not affected in the learning process.

Within the framework of a single educational program, several individual trajectories are distinguished in the model of personality-oriented education developed by the authors of this research. Students choose these trajectories in accordance with their personal inclinations and preferences. Each trajectory of education presupposes a set of competencies to be formed and developed through university education.

\section{Questions and methods}

\subsection{Methods}

In the context of the implementation of a competencies-based approach in education, students obtain professional competencies that are necessary for a 
university graduate for successful professional activity at innovative enterprises in the industrial sector of the economy (INTERNATIONAL ENGINEERING ALLIANCE, 2017d). In Europe, lists of competencies were formed for first-, second- and third-degree programs, which are given in the Dublin Descriptors (European Association for Quality Assurance in Higher Education, 2017; Shared «Dublin» descriptors for Short Cycle, First Cycle, Second Cycle and Third Cycle Awards, 2004) formulated by the European Association for Quality Assurance in Higher Education. This document presents the requirements for the competencies of graduates of the first- and second-degree programs as follows: knowledge, application of knowledge, application of solutions, communication, and self-learning. Qualification requirements for the thirddegree (engineer) program were developed later. This work was carried out in a project, namely EUR-ACE (European Accredited Engineer) (EUR-ACE FRAMEWORK STANDARDS AND GUIDELINES, 2015; EURECOM, 2014) in which Russia participated.

In Russia, the Association of Engineering Education of Russia (AEER), which includes representatives from several technical universities in Russia, is responsible for the accreditation of higher education programs. This project gives graduates the opportunity to obtain the status of a European engineer with inclusion in the register of European engineers of FEANI, in other words, it gives the right to work in any European country.

In this work, the authors design a set of professional competencies necessary for the implementation of professional activities in high-tech industries in the field of Mechanical Engineering in accordance with the educational programs of the EUR-Ace standard. It is necessary to consider the decomposition of one of the core competencies on the example of the activities of an industrial-technological bachelor's in the field of Mechanical Engineering. The professional activity of any engineer is carried out at an industrial enterprise where a technical specialist serves production processes and ensures high-quality performance of the technological process of product manufacture. To train students for industrial-technological activities, it is necessary to pay great attention to the development of technical capabilities and, above all, the formation and development of professional competencies for industrial and technological activities.

Thus, the formation and development of an industrial-technological competency is one of the necessary conditions for the successful professional activity of a future specialist. This implies proficiency in innovative high-tech methods for manufacturing competitive products, including mastery of applied professional 
programs, design of technological processes for the manufacture of products, development of individual operations of the technological process, writing of programs, adjustment and installation of equipment for operations, analysis and synthesis of projected variants of the technological process, etc.

Reviewing the requirements to an engineer formulated in the form of competencies in the new generation standards, the author of this research (as a result of cooperation with employers of high-tech industries) formulated the components of the industrial-technological type of a bachelor's activity in the field of "Mechanical Engineering" presented in Table 1.

The author of this research defines industrial-technological competency as an integrative characteristic of a graduate's ability and preparedness manifested in the planning of technological processes for the manufacture of products based on the proficiency in the methods of manufacturing products on various types of equipment, as well as using applied professional programs in the field of mechanical engineering, other information technologies and design tools, which are valid for the optimal solution of the established production tasks in conditions of rapid changes in techniques and technologies.

The motivational component is based on the presence of a positive attitude and constant interest in future industrial-technological activities, which are achieved through the implementation of integrated interdisciplinary projects and training with the use of modern high-tech equipment.

The cognitive component is based on the knowledge of the theoretical foundations of planning technological processes for the manufacture of products, the acquisition of skills, the formation of capabilities required to create technological documentation, the identification of the priority tasks of the project, as well as the creation of algorithms for finding optimal solutions to the problems under study and for mastering the fundamentals of computer graphics, programs, and electronic resources.

The cognitive component is based on:

- the knowledge of the theoretical foundations of the design of technological processes for manufacturing products;

- the acquisition of skills, as well as the formation of the ability to create technological documentation;

- highlighting the priority tasks of a project; creating algorithms for finding optimal solutions to the problems studied; 
- mastering the fundamentals of computer graphics and applied professional information programs, as well as electronic resources.

The activity component, which is based on a set of abilities and skills, includes methods of manufacturing competitive products, the ability to create new technological processes of manufacturing products and modernizing existing industrial processes.

The reflexive-evaluative component includes the analysis and evaluation of one's industrial-technological activities, the evaluation of the planned technological and industrial processes of manufacturing products in terms of cost, increase in labor productivity, and the use of modern high-tech equipment.

Table 1. The structure of the industrial-technological competency.

\begin{tabular}{|c|c|c|}
\hline Activity type & $\begin{array}{l}\text { Assessment } \\
\text { criteria }\end{array}$ & Component action-competencies \\
\hline \multirow[t]{17}{*}{$\begin{array}{l}\text { Industrial- } \\
\text { technological } \\
\text { competency }\end{array}$} & \multirow[t]{3}{*}{ Motivational } & $\begin{array}{l}\text { Demonstrates a positive attitude towards the } \\
\text { planning of production and technological processes } \\
\text { for the manufacture of products }\end{array}$ \\
\hline & & Shows a constant interest in industrial-technological activities \\
\hline & & Realizes the significance of industrial-technological activities \\
\hline & \multirow[t]{4}{*}{ Cognitive } & $\begin{array}{l}\text { Analyzes the assigned industrial task on the basis of the } \\
\text { knowledge of industrial - - technological activities }\end{array}$ \\
\hline & & $\begin{array}{l}\text { Determines the tasks for the search for optimal } \\
\text { solutions to the planning of technological processes } \\
\text { for the manufacture of products }\end{array}$ \\
\hline & & Reveals the best ways of manufacturing products \\
\hline & & $\begin{array}{l}\text { Adopts optimal solutions to manufacturing problems that } \\
\text { arise in the process of manufacturing products }\end{array}$ \\
\hline & \multirow[t]{8}{*}{ Activity } & Uses information technology in the manufacture of products \\
\hline & & $\begin{array}{l}\text { Creates documents that are part } \\
\text { of the technological documentation }\end{array}$ \\
\hline & & $\begin{array}{l}\text { Develops technological processes for manufacturing parts of } \\
\text { the required quality with a minimum cost }\end{array}$ \\
\hline & & Produces alternative means of equipment and automation \\
\hline & & Applies high-tech ways of manufacturing products \\
\hline & & Participates in the modernization of technological processes \\
\hline & & Creates programs for the operation of processing products \\
\hline & & develops and implements optimal technologies \\
\hline & \multirow{2}{*}{$\begin{array}{l}\text { Reflexive- } \\
\text { evaluative }\end{array}$} & Conducts analysis of industrial-technological activities \\
\hline & & Assesses industrial-technological activities \\
\hline
\end{tabular}

Fonte: SAVELEVA, 2015. 
Modernization of industry in Russia provides the transition to high-tech methods of manufacturing products and, accordingly, the use of modern innovative equipment in industrial processes. At the moment, in the labor market there is more demand for specialists who are capable of serving the latest equipment and are proficient in modern applied information technologies. As a consequence, one of the most important aspects of training bachelors in the technical field for high-tech industries is the formation of professional competencies in the field of information technologies. Another important role is attributed to the integrated discipline "Information Technologies in Professional Activities", which includes "Computer Science", "System of Automated Design of Technological Processes", and "Programming of CNC Machines". Students study the discipline in integration with the majority of general and special disciplines as reflected in the model (Figure 1) proposed by the author of this research.

As a result of the analysis, the author formulated the objectives of training bachelors, namely the formation of professional competencies (industrial-technological, design-engineering, and research) and the development of the most relevant components in the technical field.

To improve the quality of training bachelors, a model was created to train bachelors in the technical field (Figure 1).

This training model was applied throughout the entire period of study. After being taught one program in their first year of study, each student chose one of the three training areas in the second year: research, industrial-technological, or design-pengineering. During further training, students carried out all the projects in accordance with the chosen area. All the practical assignments and projects were performed on high-tech equipment assembled in the laboratory of the university. Practice in production was also carried out in accordance with the chosen educational trajectory. Teaching of all special disciplines was accompanied by teaching applied professional programs (AutoCAD, SolidWorks, Compass, etc.). Thus, all professional skills were obtained in the information field of the future specialty.

The peculiarity of this model is the expansion of the study of information technologies due to the variable component that will allow studying the fundamentals of general and special disciplines and then acquire professional abilities and skills in the use of information technologies and implement term projects and practical assignments only in an electronic version with the use of applied professional programs used in real production. This will allow students to form professional competencies for carrying out successful industrial activities in the future or pursuing a master's degree. 


\section{Results}

As a consequence, the author of the research developed a program related to one of the key disciplines, namely "Information Technologies in Professional Activities" in the training of future bachelors, as well as identified and substantiated pedagogical conditions for increasing the effectiveness of the

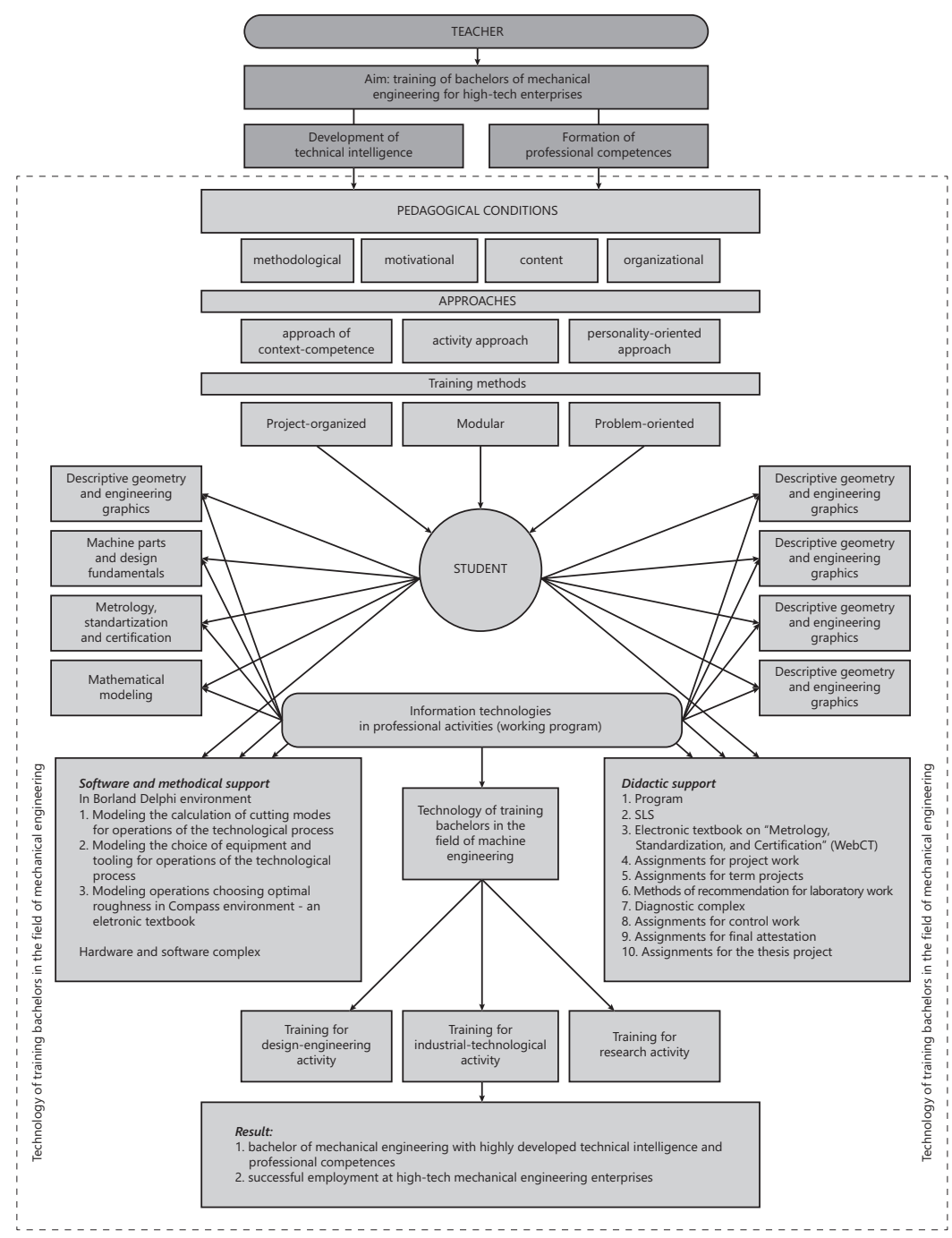

Fonte: SAVELEVA, 2015.

Figure 1. Model of training bachelors of technical profile. 
educational process. On the basis of pedagogical conditions, the author created a model of personality-oriented training of bachelors in the technical field. In the proposed model of teaching students for high-tech industries, special attention is paid to the training component that uses modern information and communication technologies since modern applied professional programs are used to service innovative equipment. In addition, the author proposes unique training programs in the Borland Delphi environment designed to solve tasks related to the modeling of various technological processes and operations in high-tech enterprises. These programs provide an interactive mode of research and operational management of the engineering process, as well as allow students to examine production tasks and find optimal solutions to the established tasks and problems.

The goal of the research was to confirm the effectiveness of the personalityoriented model of training bachelors for professional activities in high-tech enterprises.

For a long time, Russian higher educational institutions used the traditional system of education, which was aimed at developing solid professional knowledge. It formed exactingness and prepared in-demand specialists. The traditional educational system has a number of drawbacks, in particular, the reproductive ways of learning prevail, and the university eventually prepares a standard specialist who is not adapted to real industrial problems. Therefore, there is a need to reform higher education. As a consequence, Russia joined the Bologna agreement in 2003.

To organize students' education, it is necessary:

1. To identify students' individual inclinations to professional activity: industrialtechnological, design-engineering, or research. Throughout the entire learning period, training will be conducted in accordance with the latter.

2. To conduct training on high-tech equipment or simulators that will repeat the real production tasks.

3. The educational process should be accompanied by teaching modern information technologies applied in the future professional field.

In her study of individual-psychological peculiarities of an engineer's personality, E.S. Chugunova notes: “[...] the nature and content of engineers' labor distinguish them into a specific socio-professional group, and the training of their activities requires a special approach" (CHUGUNOVA, 1991). 
In addition, in conjunction with employers, it is important to form qualification requirements that graduates need for successful professional activity in high-tech enterprises. The qualification characteristics of future engineers should give the right to carry out engineering activities in the countries of Europe and America, in other words, they should meet international educational standards.

To use the proposed model in training, the author of the research developed unique training programs in the Borland Delphi environment, which are designed for students to solve problems in the modeling of various technological processes and operations in high-tech mechanical engineering enterprises. The training programs include: "selection of equipment and tooling for operations of technological processing", "modeling of operations of the technological process obtaining optimal parameters of accuracy", "modeling of the calculation of cutting modes", etc. At the same time, the programs provide an interactive mode of research, as well as allow students to examine production tasks and find optimal solutions to the established tasks and problems.

At the end of the experiment, the effectiveness of the development of professional competencies in learners was assessed according to the results of ascertaining and forming experiments.

The research was carried out in 2009-2014 at the Department of "Technologies of Automated Mechanical Engineering" in the Tomsk Politechnic University and involved students studying Mechanical Engineering. The experiment involved 128 people (including three girls) in the control group and 74 people (including three girls) in the experimental group. The control group involved Mechanical Engineering students (future bachelors; duration of education - 4 years) of five groups, trained by the method proposed by the author. The control group consisted of students from three groups who studied "Technology of Mechanical Engineering" for five years. The experiment was organized in the following way: the model of personality-oriented training of bachelors was applied in the experimental group, and the traditional training method was applied in the control group.

In the experimental group, each student's inclinations to the types of professional activity were revealed at the beginning of the experiment (in the first year). Psychological tests used to establish the inclinations include Anne Mahoney's "Constructive Image of a Person", D. Holland's "Questionnaire of Professional Preferences”, and H. Eysenck's Questionnaire.

A diagnostic complex was used to assess the development level of students' professional competencies. It included questions, assignments, assignments for 
control works, tests for current and final control works, as well as assignments for a thesis project and integrated final attestation. It is necessary to point out that basically, the cognitive component of the learning outcome is tested (BLACK, 1999).

Within the framework of experimental teaching at the Department of Technologies of Automated Mechanical Engineering in the Tomsk Politechnic University, the author of this research proved the effectiveness of the model developed.

At the ascertaining stage of the experiment, the author used input control tests to determine the development levels of professional competencies of students in the control and experimental groups.

At the forming stage of the experiment, the development levels of competencies were assessed according to the types of professional activity consistently through students' control works, final tests, and practical assignments. The results of the latter were evaluated by the methods proposed by Gibbs (1995).

$$
\mathrm{k}=\frac{\sum_{i=1}^{\mathrm{N}} \mathrm{n}_{\mathrm{i}}}{=} \text {. }
$$

where $\mathrm{k}$ is the efficiency of the task, the assimilation of new educational material; $n_{i}$ is the number of points the $i^{\text {th }}$ student receives for answering questions and performing the necessary actions and operations;

$\mathrm{N}$ is the number of students;

$\mathrm{n}$ is the maximum number of points for performing the exercises.

The following three levels of development of the bachelors' professional competencies were accepted: medium, high, and creative (Table 2).

Table 2. The efficiency factor and levels of development of future bachelor's professional competencies.

\begin{tabular}{lc}
\hline Levels of professional competencies & Efficiency factor \\
\hline Medium & $0.3 \leq \mathrm{k} \leq 0.5$ \\
High & $0.5<\mathrm{k} \leq 0.75$ \\
Creative & $0.75<\mathrm{k} \leq 1$ \\
\hline
\end{tabular}

Fonte: SAVELEVA, 2015. 
The assessment of $2^{\text {nd }}$ - and $3^{\text {rd }}$-year students was based on the quality of executed projects and professional orientation, which allowed assessing the intermediate level of the professional competencies formed.

In the fourth year of study, assessment was based on the quality of diploma projects related to the planning of technological processes, design of technological equipment, etc., which allows the author to assess the final level of the professional competencies formed.

Table 3 presents the results of the study in all the four stages of the experiment.

Figure 2 presents the experiment results in average levels of development of professional competencies (in points) in the experimental and control groups.

The diagram shows the growing level of the formation of professional competencies in the process of the experiment. Moreover, in the experimental group, the level of development of professional competencies significantly increased, namely from 19 to 89 points. In the control group, the level of development of professional competencies grew only to 67 points, which confirms the effectiveness of the implementation of the model of training bachelors.

Table 3. Research results.

\begin{tabular}{lcccccc}
\hline & \multicolumn{5}{c}{ Levels of professional competencies formed (points) } \\
\cline { 2 - 6 } & $\begin{array}{c}\text { Number } \\
\text { of } \\
\text { students }\end{array}$ & $\begin{array}{c}\text { Number } \\
\text { of tasks }\end{array}$ & $\begin{array}{c}\text { Maximum } \\
\text { number } \\
\text { of points }\end{array}$ & $\begin{array}{c}\text { Number } \\
\text { of points } \\
\text { received } \\
\text { by } \\
\text { students }\end{array}$ & $\mathbf{K}$ & $\begin{array}{c}\text { Program } \\
\text { modules }\end{array}$ \\
\hline Control & 128 & 20 & 100 & 22 & 0,22 & $1^{\text {st }}$ year \\
Experimental & 74 & 20 & 100 & 29 & 0.29 & \\
Control & 128 & 10 & 100 & 37 & 0.37 & $2^{\text {nd }}$ year \\
Experimental & 74 & 10 & 100 & 41 & 0.41 & \\
Control & 128 & 10 & 100 & 48 & 0.48 & $3^{\text {rd }}$ year \\
Experimental & 74 & 10 & 100 & 56 & 0.56 & \\
Control & 128 & 10 & 100 & 67 & 0.67 & $4^{\text {th }}$ year \\
Experimental & 74 & 10 & 100 & 89 & 0.89 & \\
\hline
\end{tabular}

Fonte: SAVELEVA, 2015. 


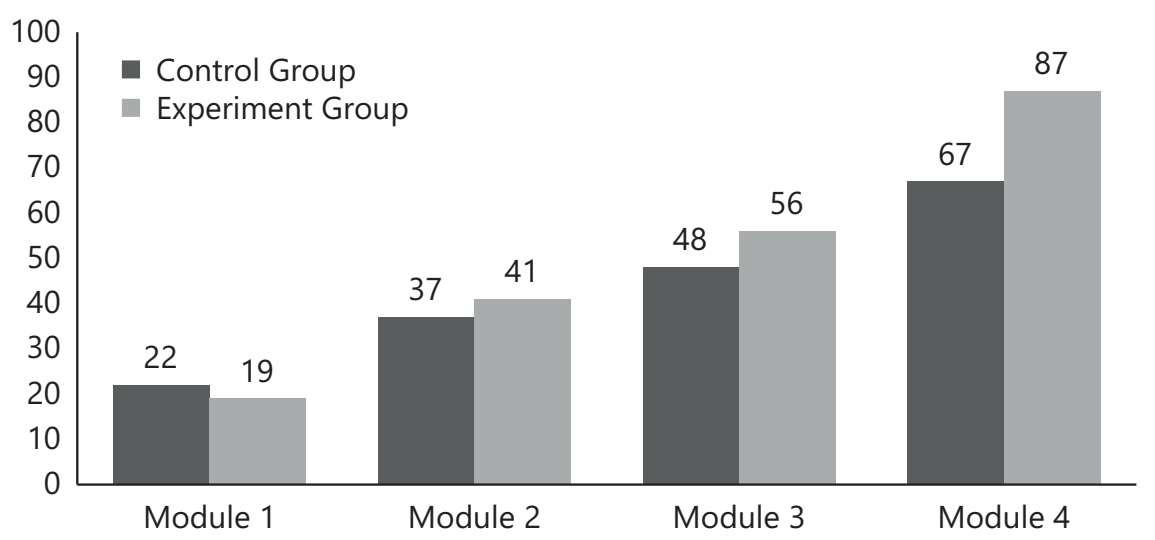

Fonte: SAVELEVA, 2015.

Figure 2. Diagram of changes in the average levels of development of professional competencies (in points).

\section{Discussion}

The rapid development of society, the expansion of opportunities for professional choice, the transition to an information society and production, and the globalization of the international community require a change in professional education. Industry is on the way to reducing unskilled labor, which requires an increase in the level of professional training and mobility. In the European Union, for successful employment, a person has to change his qualifications for several times during his life (HUTMACHER, 1997).

A number of authors actively study the problem of training personnel for scienceintensive high-tech industries (CHUCHALIN ET AL., 2006; EUROPEAN FEDERATION OF NATIONAL ENGINEERING ASSOCIATIONS, 2017; SAVELEVA, 2016b; SELF-STUDY REPORT FOR REVIEW OF THE PROGRAM..., 2001) and observe a change in the mechanisms of forming professional competencies in accordance with a students' individual inclinations.

In developed countries, the role of human capital (KEMBER, 1997) keeps growing, which enhances the requirements for the quality of professional training. Therefore, the tendencies of improving higher education are related to the expansion of students' ability to independently choose an educational trajectory, taking into account their inclinations and potential (STEPHENSON; TROY, 2003). This implies flexibility and variability of educational programs, and their revision in accordance with the requirements of demand for specific categories of specialists (MEIJERS et al., 2005). 


\section{Conclusion}

One of the results of this research carried out on the basis of the resource center of Tomsk Polytechnic University is related to the development of a model for training bachelors. The model successfully passed practical approbation and can be recommended for wide use in professional educational organizations. Further research on this subject may include the training of masters and post-graduates for high-tech industries. A study on the training of bachelors of technical profile for effective work in high-tech industries is currently being carried out at the Tyumen Industrial University Branch in Nizhnevartovsk. The author of the research deals with the problem of training workers and specialists for the hightech oil and gas industry.

\section{Acknowledgements}

The author of the research expresses her gratitude to her scientific adviser Irina Yuryevna Sokolova, Dr. habil. in Pedagogy, Professor at the Tomsk Polytechnic University, for valuable advice on the planning of the research and recommendations on the formulation of this article. 


\section{Um modelo de formação orientada ao pessoal de licenciaturas do perfil técnico para as indústrias de alta tecnologia}

\section{Resumo}

O ensino superior na Rússia está agora dividido em duas etapas: Bacharelado e Mestrado. Lamentavelmente, o processo educacional dos estudantes de bacharelado revelou a preparação insatisfatória de jovens especialistas, que precisam passar por mais treinamento e adaptação a uma indústria de alta tecnologia. A falta de competências profissionais dos estudantes de graduação é bastante decepcionante para os empregadores. Portanto, torna-se vital melhorar o processo educacional e implementar mudanças significativas no sistema metodológico de educação. É necessário abranger as tecnologias da informação. Este estudo é dedicado ao programa educacional para engenheiros mecânicos, que foi desenvolvido de acordo com os principais requisitos dos empregadores. A eficácia desta abordagem de treinamento foi comprovada durante o experimento de pesquisa. Provou-se a hipótese de que o modelo aprimorado de treinamento dos alunos leva a um processo de estudo mais ativo e eficaz; incorpora uma abordagem individual para cada aluno e contribui para um desenvolvimento mais eficiente das competências profissionais.

Palavras-chave: Preparação orientada para a personalidade. Atividades de design. Atividades produtivas e tecnológicas. Atividades de pesquisa. Fabricação de alta tecnologia.

\section{Un modelo de entrenamiento orientado a la formación personalizada de licenciados de perfil técnico para industrias de alta tecnología}

\section{Resumen}

La educación superior en Rusia ahora se divide en dos etapas: Licenciatura y Maestría. Lamentablemente, el proceso educativo de los estudiantes de bachillerato ha revelado la preparación insatisfactoria de jóvenes especialistas que deben someterse a una mayor capacitación y adaptación a una industria de alta tecnología. La falta de competencias profesionales de los estudiantes graduados es bastante decepcionante para los empleadores. Por lo tanto, se vuelve vital mejorar el proceso educativo e implementar cambios significativos en el sistema metodológico de educación. Es necesario abarcar las tecnologías de la información. Este estudio está dedicado al programa educativo para ingenieros mecánicos, que se ha desarrollado de acuerdo con los principales requisitos de los empleadores. La efectividad de este enfoque de entrenamiento fue probada durante el experimento de investigación. Demostró la hipótesis de que el modelo mejorado de capacitación de los estudiantes conduce a un proceso de estudio más activo y efectivo; incorpora un enfoque individual para cada estudiante y contribuye a un desarrollo más eficiente de las competencias profesionales.

Palabras clave: Preparación orientada a la personalidad. Actividades de diseño. Producción y actividades tecnológicas. Actividades de investigación. Fabricación de alta tecnología. 


\section{References}

BATYSHEV, S. Y. Predictive orientation of professional education. Pedagogy, v. 6, p. 22-7, 1998.

BLACK, P Assessment, learning theories and testing systems. In: MURPHY, P. (Eds.). Learners, learning and assessment. London: Open University Press, 1999. p. 118-34.

CHALETA, M. E. Concepções de aprendizagem em estudantes do ensino superior: Reanálise do COLI (Inventário de Concepções de Aprendizagem). Ensaio: Avaliação e Políticas Públicas em Educação, v. 26, n. 100, p. 684-705, jul. 2018. https://doi.org/10.1590/s0104-40362018002601302

CHUCHALIN, A. et al. Quality of engineering education: world trends in terms of competencies. Higher Education in Russia, v. 8, p. 9-18, 2006.

CHUGUNOVA, E. S. Comprehensive socio-psychologicalmethods of studying the personality of an engineer. Leningrad: Leningrad State University, 1991.

ENGINEERING TECHNOLOGISTS MOBILITY FORUM 2017, 2017.

Washington, DC: Internatioal Engineering Alliance, 2017. Available from: $<$ http://www/ieagreements.com/ETMF/default.cfm>. Access in: 2017 Oct. 9.

ENGINEERS MOBILITY FORUM. 2017, 2017. Washington, DC:

Internatinoal Engineering Alliance, 2017. Available from: <http://www. ieagreements.org/>. Access in: 2017 Oct. 9.

EUR-ACE FRAMEWORK STANDARDS AND GUIDELINES. Brussels:

European Network for Accreditation of Engineering Education, 2015. Available from: <http://www.enaee.eu/wp-assets-enaee/uploads/2015/04/EUR-ACEFramework-Standards-and-Guidelines-Mar-2015.pdf>. Access in: 2017 Oct. 9.

EURECOM 2014. Available from: <http://eurace.enaee.eu/>. Access in: 2017 Oct. 9.

EUROPEAN FEDERATION OF NATIONAL ENGINEERING

ASSOCIATIONS. Brussel, 2017. Available from: <http://www.feani.org>. Access in: 2017 Oct. 9.

GIBBS, G. Assessing student-centered courses. Oxford: Oxford Centre for Staff Learning and Development, 1995. 
FERREIRA, N. S. P.; PACHECO, J. A.. As políticas de formação de pesquisadores: análise comparativa (Portugal-Brasil) em contextos de programas de pós-graduação. Ensaio: Avaliação e Políticas Públicas em Educação, v. 17, n. 65, p. 719-28, dez. 2009. http://dx.doi.org/10.1590/S0104-40362009000400009

GURGEL, C. R.; AGUIAR, G. E.; SILVA, N. N. Avaliação como espaço de aprendizagem em softwares educativos. Ensaio: Avaliação e Políticas Públicas em Educação, v. 21, n. 79, p. 371-88, jun. 2013. https://doi. org/10.1590/S0104-40362013000200010.

HUTMACHER, W. Key competencies for Europe. In: SYMPOSIUM BERNE, 1996, Switzezland, 1996. Report... Strasburg, Council for Cultural Cooperation, 1997. Engineering Technologists Mobility Forum. Available from: $<$ http://www/ieagreements.com/ETMF/default.cfm>. Access in: 2017 Oct. 9.

INTERNATIONAL ENGINEERING ALLIANCE. Graduate attributes and professional competencies. Washington, DC, 2017d. Available from: $<$ http://www.ieagreements.org/assets/Uploads/Documents/Policy/GraduateAttributes-and-Professional-Competencies.pdf $>$. Access in: 2017 Oct. 9.

. The Dublin accord. Washington, DC,2017c. Available from: $<\mathrm{http}: / /$ www/ieagreements.com/Dublin/DublinFoundation.cfm>. Access in: 2017 Oct. 9. . The Sydney accord. Washington, DC, , 2017b. Available from: $<$ http://www/ieagreements.com/Sydney>. Access in: 2017 Oct. 9.

. The Washington accord. Washington, DC, 2017a. Available from: $<$ http://www.washingtonaccord.org $>$. Access in: 2017 Oct. 9.

KEMBER, D. A reconceptualisation of the research into university academics conceptions of teaching. Learning and Instruction, v. 7, n. 3, p. 255-75, Sep. 1997. https://doi.org/10.1016/S0959-4752(96)00028-X

MEIJERS, A. W. M. et al. Criteria vooracademische bachelor en master curricula = Criteria for academic bachelor's and master's curricula. Eindhoven: TechnischeUniversiteit Eindhoven, 2005. Available from: $<$ http://repository.tue. nl/712e8f70-9e15-41db-af9f-d5551bb3d81e>. Access in: 2017 Oct. 9.

O'SULLIVAN, M. The reconceptualisation of learner-centred approaches: a Nambian case study. International Journal of Educational Development, v. 24, n. 6, p. 585-502, Nov. 2003. https://doi.org/10.1016/S0738-0593(03)00018-X 
SAVELEVA, N. N. Personality-oriented approach of training bachelors of mechanics for high-tech industries. Modern High Technologies, n. 2, pt. 3, p. 557-60, $2016 \mathrm{a}$.

Preparation of future bachelors-oil workers for professional work in high-tech enterprises. Tyumen:, TIU Publication, 2017.

. Principles of modernizing the system of multilevel education of personnel training in the oil and gas industry. Modern High Technologies, n. 9, pt. 2, 327-32, 2016 b.

. The choice of an engineering profession by school children: experience of Russia. Astra Salvensis, v. 6, n. spe, 675-682, 2018.

COLORADO SCHOOL OF MINES. Self-study report for review of the programme leading to the degree of bachelor of science in engineering by the ABET. Golden: Colorado School of Mines; 2001.

SLASTENIN, V. A. Humanistic paradigm and personality-oriented technologies in pedagogical education. Moscow: Pedagogika, 1999

SOARES, N. S. Transdisciplinary education and the art of learning: a pedagogy of self-development for human development. Salvador: EDUFBA, 2006.

SOKOLOVA, I. Y. Psychological support of the quality of the educational process: textbook. Tomsk: Tomsk Polytechnic University, 2003.

SOKOLOVA, I. Y.; TEREKHINA, L. A. Educational environment for the development of students' personal potential, preservation and the strengthening of their health. Modern Problems of Science and Education, n. 3, p. 246-7, 2013.

SOLOVOV, A. V. Electronic learning: problems, didactics, technology. Samara: Novaya Tekhnika. 2006.

STEPHENSON, L. S. J. D.; TROY, J. Higher education students' attitudes to student-centered learning: beyond 'educational bulimia'. Studies in Higher Education, v. 28, n. 3, p. 321-34, 2003.

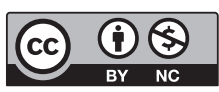

\section{Informações da autora}

Nataliya Nikolaevna Saveleva: Ph. D. in Pedagogical Sciences, Professor Department of Petroleum Engineering Industrial University of Tyumen. Contato: saveleva.iut@bk.ru 